\title{
MAPPING OF MANGROVE VEGETATION USING LANDSAT SATELLITE IMAGERYIN THE ESTUARY OF GANGSAL RIVER INDRAGIRI HILIR REGENCY RIAU PROVINCE
}

\author{
Hendri Susilo $^{1 *}$, Musrifin Galib ${ }^{2}$, Aras Mulyadi ${ }^{2}$ \\ ${ }^{1}$ Student of The Faculty of Fisheries and Marine Science University of Riau, Pekanbaru \\ ${ }^{2}$ Lecturer at The Faculty of Fisheries and Marine Science University of Riau, Pekanbaru \\ *Hendri.greendust@gmail.com.
}

\begin{abstract}
The research was conducted in January - March 2019. This study aims to map and analyze changes in the area and density of mangrove vegetation based on NDVI values and community structure in the Muara Sungai Gangsal, Indragiri Hilir Regency. To analyze the area and density of NDVI using Landsat 5 TM satellite imagery in 2008 and Landsat 8 OLI/TIRS in 2018. Analysis using ArcGis 10.3 software. The calculation of mangroves based on community structure used the Transect Line Plot method at 6 stations for community structure sampling. The area of mangrove vegetation in 2008 was 2,706 ha and in 2018 it was 2,693 ha. The results of the analysis of mangrove vegetation area from 2008 to 2018 there was a reduction of 13 ha. The NDVI value for 2008 criteria is rarely 133 ha, while 2.009 ha are wide and 564 ha is dense. The NDVI value of the 2018 mangrove vegetation is rarely 16 hectares, while 2,135 hectares are in the area and 542 hectares are dense. Based on the analysis of mangrove density in 2018 at 6 sampling point stations ranging from $866 \mathrm{ind} / \mathrm{ha}$ to $1,522 \mathrm{ind} / \mathrm{ha}$. Density criteria are rarely detected at station I with a density of $922 \mathrm{ind} / \mathrm{ha}$ and station II with a density of $866 \mathrm{ind} / \mathrm{ha}$. The criterion of moderate density was detected at station $\mathrm{V}$ with a density of $1,255 \mathrm{ind} / \mathrm{ha}$ and station VI with a density of 1,044 ind/ha. Criteria for solid density were detected at station III with a density of 1,522 ind/ha and station IV with a density of $1,511 \mathrm{ind} / \mathrm{ha}$.
\end{abstract}

Keywords: Estuary of Gangsal River, Mangrove, Landsat, Density, NDVI

\section{PENDAHULUAN}

Hutan mangrove adalah hutan yang tumbuh di atas rawa-rawa berair payau yang terletak di garis pantai dan dipengaruhi oleh pasang-surut air laut. Hutan mangrove ini khususnya tumbuh di tempat-tempat perlumpuran dan akumulasi bahan organik, seperti misalnya teluk-teluk yang terlindung dari gempuran ombak, maupun di sekitar muara sungai pada tempat perlambatan dan pengendapan lumpur yang terbawa dari hulu (Rumada $e t$ al., 2015).
Salah satu provinsi di Indonesia yang juga memiliki Vegetasi mangrove yang luas adalah Provinsi Riau. Luasnya Vegetasi mangrove di Provinsi Riau dikarenakan wilayah Provinsi Riau sebagian besar berada di wilayah pesisir terutama wilayah pesisir bagian timur yang menjadi muara sungai-sungai besar, sehingga memiliki substrat pantai berlumpur yang merupakan substrat ideal untuk mangrove, sehingga di tumbuhi vegetasi mangrove yang sangat lebat. 
Vegetasi mangrove di Provinsi Riau tersebar dibeberapa kabupaten, seperti Kota Dumai, Kabupaten Bengkalis, Kabupaten Rokan Hilir, Kabupaten Meranti, Kabupaten Pelalawan, Kabupaten Siak, dan Kabupaten Indragiri Hilir, dari beberapa kabupaten tersebut Kabupaten Indragiri Hilir merupakan kabupaten yang memiliki daerah dengan Vegetasi mangrove terluas.

Luas vegetasi mangrove di Kabupaten Indragiri Hilir berdasarkan data dari Kementerian Koordinator Bidang Kemaritiman Bekerja Sama dengan Kementerian Lingkungan Hidup dan Kehutanan pada tahun 2018 luas vegetasi mangrove di Kabupaten Indragiri Hilir dalam kondisi baik dengan luas 32.851 ha, dalam kondisi kritis diluar kawasan dengan luas 68.850 ha dan dalam kawasan 116.182 ha.

Salah satu muara sungai di Kabupaten Indragiri Hilir yang tumbuhi vegetasi mangrove lebat yaitu Muara Sungai Gangsal. Muara Sungai Gangsal terletak di Kecamatan Reteh yang memiliki vegetasi mangrove yang lebat dan luas dikarenakan mendapat pengaruh pasang surut dan banyak anak sungai (parit) yang mengalir ke Muara Sungai Gangsal membawa substrat lumpur yang ideal bagil pertumbuhan vegetasi mangrove.

Muara Sungai Gangsal merupakan jalur transportasi perairan bagi masyarakat Kecamatan Keritang dan Kecamatan Reteh, sehingga vegetasi mangrove di pesisir muara Sungai Gangsal yang berada di Kecamatan Reteh memiliki potensi besar mengalami kerusakan secara alami dan akibat pemanfaatan yang dilakukan secara berlebihan untuk perluas pemukiman, bahan bangunan, transportasi dan pembukaan lahan untuk pertanian dan perkebunan yang menjadi sumber ancaman terhadap ekosistem mangrove.

Melihat kondisi tersebut, maka penelitian sangat penting dilakukan untuk memantau kondisi vegetasi mangrove di Muara Sungai Gangsal secara spasial dan temporal dengan menggunakan sistem penginderaan jauh untuk mengetahui perubahan luas, kerapatan dan kondisi vegetasi mangrove di muara Sungai Gangsal Kabupaten Indragiri Hilir tahun 2008 dan 2018.

\section{METODE PENELITIAN}

Penelitian dilaksanakan dari bulan Januari - Maret 2019. Pengambilan data lapangan dilakukan di Muara Sungai Gangsal, Kabupaten Indragiri Hilir, Provinsi Riau. Pengolahan data citra dan analisis data dilakukan di Laboratorium Oseanografi Fisika, Jurusan Ilmu Kelautan, Fakultas Perikanan dan Kelautan, Universitas Riau.

Pada penelitian ini digunakan metode survey yaitu dengan observasi, pengambilan data lapangan (Ground Check). Stasiun penelitian ditentukan secara purposive sampling yang artinya titik stasiun penelitian di pilih secara sengaja berdasar-kan pertimbangan kondisi pesisir dengan berdasarkan hasil pengolahan data citra tahun 2008-2018 yang telah diketahui pada saat interpretasi data citra. Titik stasiun penelitian ditentukan sebanyak 6 stasiun, pada setiap stasiun terdiri dari 3 transek dan pada setiap transek terdiri dari 3 plot petak contoh (Transect Line Plot).

Data citra satelit Landsat $5 \mathrm{TM}$ tahun 2008 dan Landsat 8 OLI/TIRS tahun 2018 sebagai data untuk memetakan dan menganalisis perubahan luas dan kerapatan vegetasi mangrove.

\section{Pengolahan Data Citra}

Tahap pengolahan citra dilakukan dengan koreksi reflektan untuk merubah data dari format $\mathrm{DN}$ ke radian atau reflektan. Terdeteksi dua jenis produk luaran citra berformat reflektan yang dihasilkan, yaitu Top of Atmosphere (TOA) atau reflektan yang tertangkap sensor dan Bottom of Atmosphere (BOA) atau reflektan pada objek yang telah terkoreksi 
atmosfer. Sedangkan penggunaan kedua jenis reflektan tersebut, masih perlu diuji tingkat keefektifitasannya apabila digunakan pada algoritma indeks vegetasi (Fatimah et al., 2016).

Koreksi atmosferik menggunakan metode dark pixel correction. Prinsip metode ini adalah memperbaiki nilai radiometrik (pixel value) pada citra akibat gangguan radiometrik. Obyek berawan gelap pada data citra seharus-nya memiliki nilai piksel 0 , apabila obyek tersebut tidak bernilai 0 maka nilai tersebut adalah bias (Lilik, 2016; Kurniawan et al., 2019).

Pemotongan citra dilakukan untuk memfokuskan kajian pada daerah penelitian dan objek pada masing masing citra komposit warna semu masing-masing band. Selain itu, pemotongan citra akan mengurangi kapasitas memori sehingga memudahkan pada proses pengolahan data citra tersebut (Pinastika et al., 2013).

Pembuatan citra komposit digunakan untuk mengenali objek pada citra. Untuk memudahkan pengenalan objek pada citra maka digunakan komposit semu. Pada penelitian ini komposit yang digunakan komposit RGB453 pada Landsat-5, sedangkan komposit RGB564 pada Landsat-8 (Hendrawan et al., 2018).

Klasifikasi pada penelitian ini digunakan Klasifikasi terbimbing (Supervised), dimana citra diklasifikasikan dengan metode kemiripan maksimum (maximum likehood) (Muhammad et al., 2019), klas-klas yang digunakan yaitu klas laut dalam, klas laut dangkal, klas vegetasi mangrove, dan klas non vegetasi mangrove.
Analisis indeks vegetasi digunakan untuk memisahkan indeks reflektansi spektral vegetasi dengan objek lain seperti air, tanah (non vegetasi). Formula yang digunakan untuk analisis indeks vegetasi adalah NDVI (Normalized Defference Vegetation Index). NDVI dapat menggambarkan suatu kerapatan vegetasi berdasarkan perhitungan sederhana. Formula ini didasarkan pada nilai reflektansi dari objek dalam saluran spektrum merah dan inframerah dekat. Rumus yang digunakan yaitu:

$$
N D V I=\frac{N I R-R}{N I R+R}
$$

Dimana: NIR $=$ Near Infrared (Band 4 pada Landsat-5 dan Band 5 pada Landsat8) dan $\mathrm{R}=\operatorname{Red}$ (Band 3 pada Landsat-5 dan Band 4 pada Landsat-8) (Amliana et al., 2016).

Nilai NDVI tersebut di gunakan untuk menentukan selang dalam pengklasifikasian kerapatan mangrove. Pengklasifikasian mangrove di bagi menjadi dalam 5 kelas, yaitu darat, laut, mangrove jarang, mangrove sedang, dan mangrove lebat (Bangun dan Arindi, 2019; Pratama et al., 2019).

Secara teoritis nilai NDVI berkisar antara -1 hingga 1 namun nilai indeks vegetasi mangrove secara umum berada pada kisaran antara 0,1 hingga 0,7 , sedangkan nilai antara -1 sampai 0 menunjukan bahwa obyek tersebut bukan vegetasi (Intan et al., 2016, Cecep dan Ningrum, 2016).Kriteria kerapatan dannilai NDVI vegetasi mangrove pada Tabel 1.

Tabel 1. Kriteria kerapatan dan nilai NDVI vegetasi mangrove

\begin{tabular}{llll}
\hline No. & Kriteria & Kerapatan (Pohon/Ha) & NDVI \\
\hline 1 & Jarang & $<1000$ & $-0,10-0,32$ \\
2 & Sedang & $\geq 1000-<1500$ & $0,33-0,42$ \\
3 & Padat & $\geq 1500$ & $0,43-1$ \\
\hline \multicolumn{2}{r}{ Sumber : KepMen KLH Nomor 201Tahun 2004. }
\end{tabular}


3. HASIL DAN PEMBAHASAN

Perubahan Luas Vegetasi Mangrove Tahun 2008 dan 2018
Sebaran mangrove 2008 dan 2018 disajikan pada Gambar 1 dan 2.

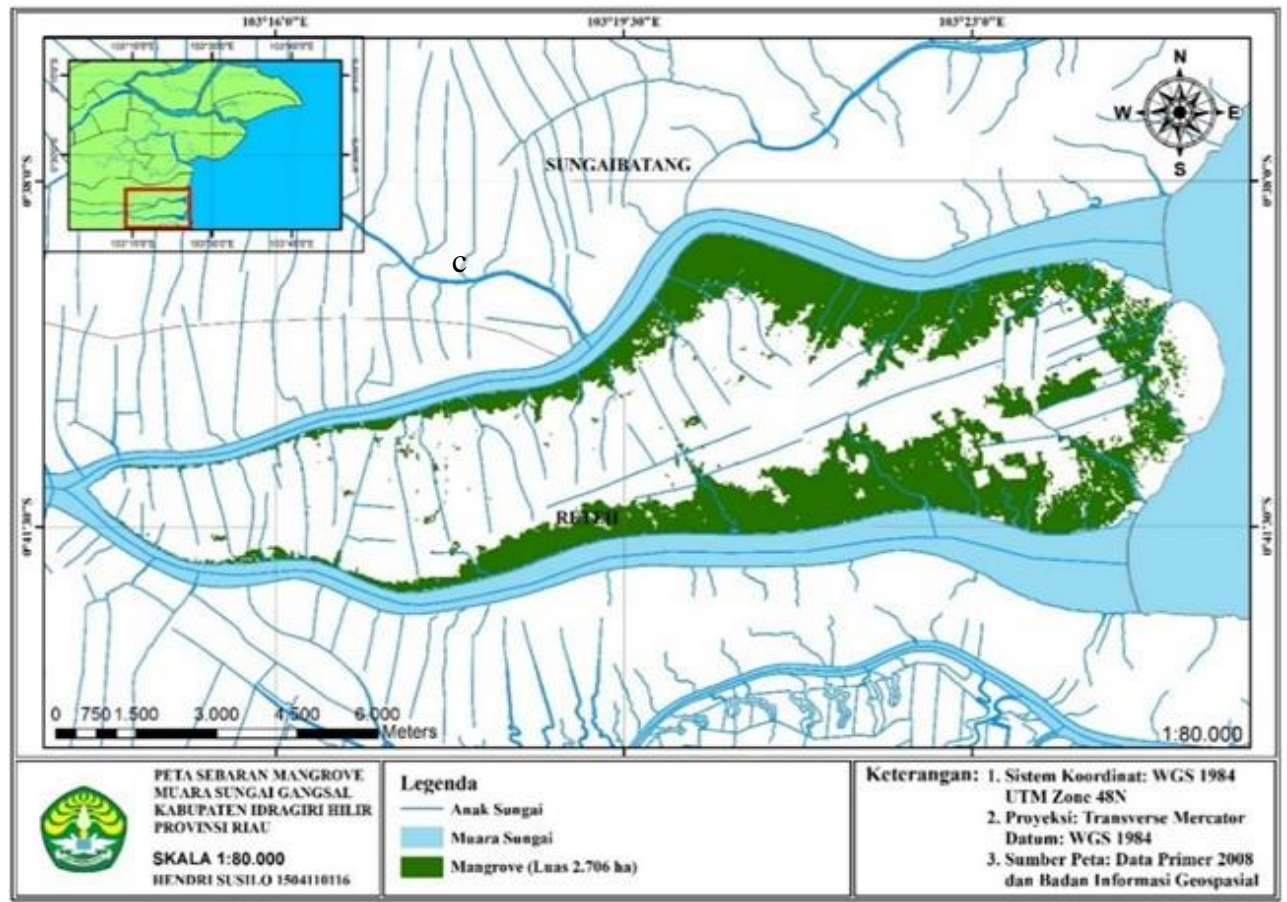

Gambar 1. Peta Sebaran Vegetasi Mangrove Tahun 2008 di Muara Sungai Gangsal.

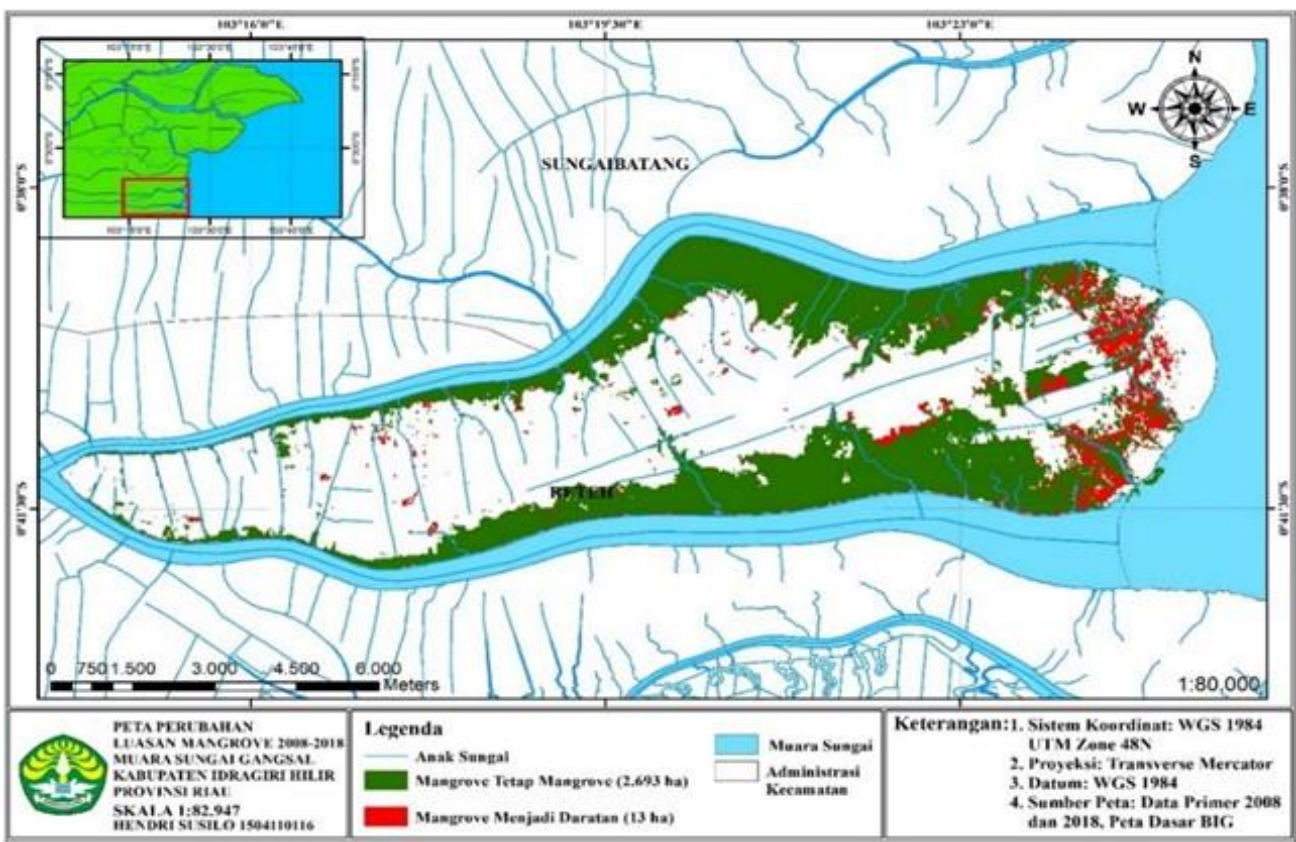

Gambar 2. Peta Sebaran Vegetasi Mangrove Tahun 2018 di Muara Sungai Gangsal.

Perubahan luas vegetasi mangrove di Muara Sungai Gangsal tahun 2008-2018 disajikan dalam Tabel 2. 
Tabel 2. Perubahan Luas Vegetasi Mangrove di Muara Sungai Gangsal Tahun 2008-2018

\begin{tabular}{|c|c|c|c|c|c|}
\hline Klasifikasi & $\begin{array}{l}\text { Luas } 2008 \\
\text { (ha) }\end{array}$ & $\begin{array}{l}\text { Luas } 2018 \\
\text { (ha) }\end{array}$ & $\begin{array}{l}\text { Penambahan } \\
\text { Luas (ha) }\end{array}$ & $\begin{array}{l}\text { Penguranagn } \\
\text { Luas (ha) }\end{array}$ & Klasifikasi \\
\hline Mangrove & 2.706 & 2.693 & - & 13 & Mangrove \\
\hline
\end{tabular}

vegetasi mangrove di Muara Sungai Gangsal 2008 dengan luas 2.706 ha dan luas mangrove hasil klasifkasi citra landsat 8 tahun 2018 dengan luas 2.693 ha. Perubahan luas vegetasi Mangrove Tahun 2008-2018 di Muara Sungai Gangsal berdasarkan hasil dari overlay (tumpang susun) di dapatkan luas vegetasi mangrove terdegradasi 13 ha.

Kondisi vegetasi mangrove di Muara Sungai Gangsal menunjukkan terjadinya penambahan dan degradasi (pengurangan) luas vegetasi mangrove. Penambahan luas terjadi karena proses lebih didominasi secara alami. Faktor yang mempengaruhi vegetasi mangrove karena habitat yang cocok dan hidrologi yang membawa biji buah dan propagul (bibit mangrove) yang dipengaruhi oleh pasang surut serta tumbuhnya propagul dan biji buah mangrove yang jatuh dari pohonya menyebabkan pertambahan luas. Degradasi vegetasi mangrove di Muara Sungai Gangsal di akibatkan oleh faktor alih fungsi lahan menjadi kawasan tambak dan kawasan perkebunan milik masyarakat.

Menurut Aji et al. (2017), aktivitas manusia yang dapat menyebabkan perubahan lahan mangrove antara lain adalah penebangan liar, kebutuhan akan kayu bakar rumahan, rendahnya pengetahuan masyarakat akan berbagai fungsi mangrove.

Perubahan luas vegetasi mangrove yang terjadi juga dapat disebabkan dinamika pasang surut perairan pada saat perekaman data citra satelit. Perekaman data pada saat pasang dapat menyebabkan wilayah daratan yang tergenang oleh perairan akan lebih banyak dibandingkan pada saat surut (Nadya et al., 2019).

Menurut Nurul et al. (2018), pada beberapa kasus, piksel dari kategori mangrove dapat bercampur dengan kategori laut dan jika satelit melakukan perekaman pada saat pasang tertinggi maka kemungkinan mangrove jenis Rhizophora sp atau mangrove jenis lain yang memiliki tinggi lebih rendah dari pasang air laut maka akan tertutup oleh air pasang sehingga hal ini menyebabkan pencampuran dengan kategori lainnya.

Berdasarkan hasil klasifikasi citra menunjukkan bahwa sebaran mangrove di pesisir Muara Sungai Gangsal membentuk green belt atau sabuk hijau yang berfungsi sebagai penyangga ekosistem pantai yang tersebar mengikuti garis pantai. Mangrove merupakan ekosistem yang mampu bertahan hidup di dearah tepi pantai yang dipengaruhi oleh pasang surut air laut, sehingga lokasi mangrove selalu tergenang oleh air yang memiliki kadar fluktuasi salinitas tinggi (Susiana, 2015).

\section{Kerapatan Vegetasi Mangrove Tahun 2008 dan 2018 Berdasarkan Nilai NDVI}

Perbedaan hasil klasifikasi nilai NDVI dalam menentukkan tingkat kerapatan mangrove 2008 dan 2018 dapat dilihat pada Gambar 3 dan 4. 


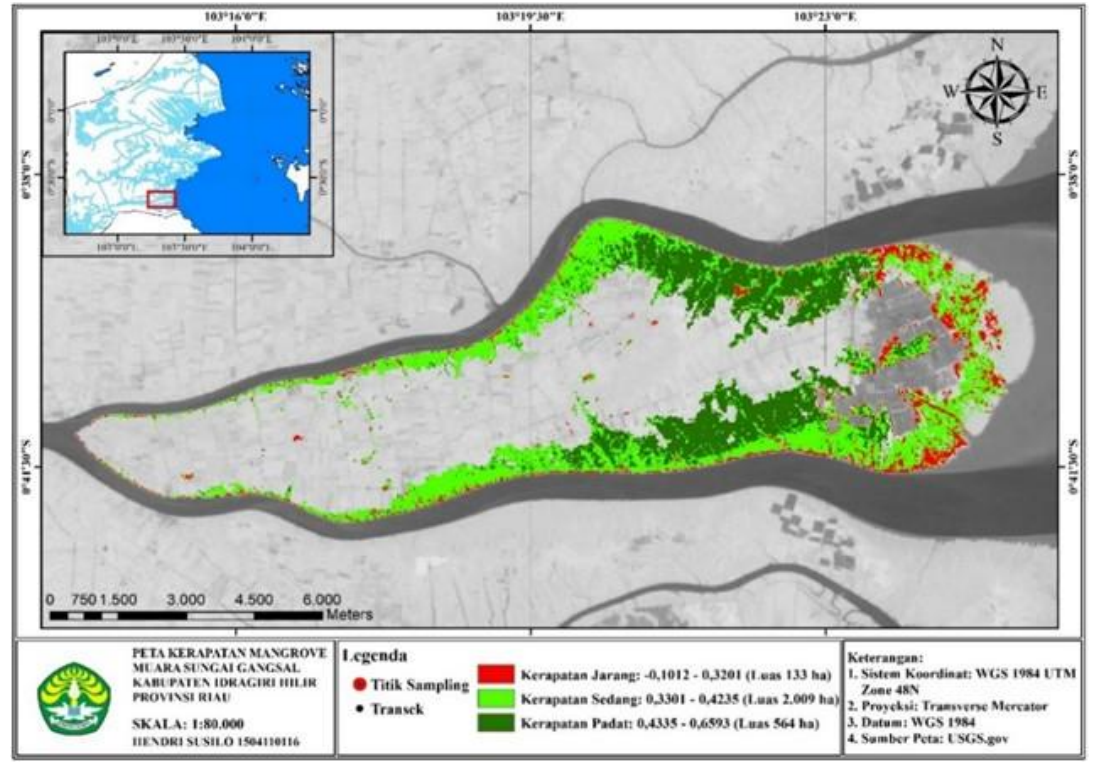

Gambar 3. Peta Kerapatan Vegetasi Mangrove di Muara Sungai Gangsal Tahun 2008.

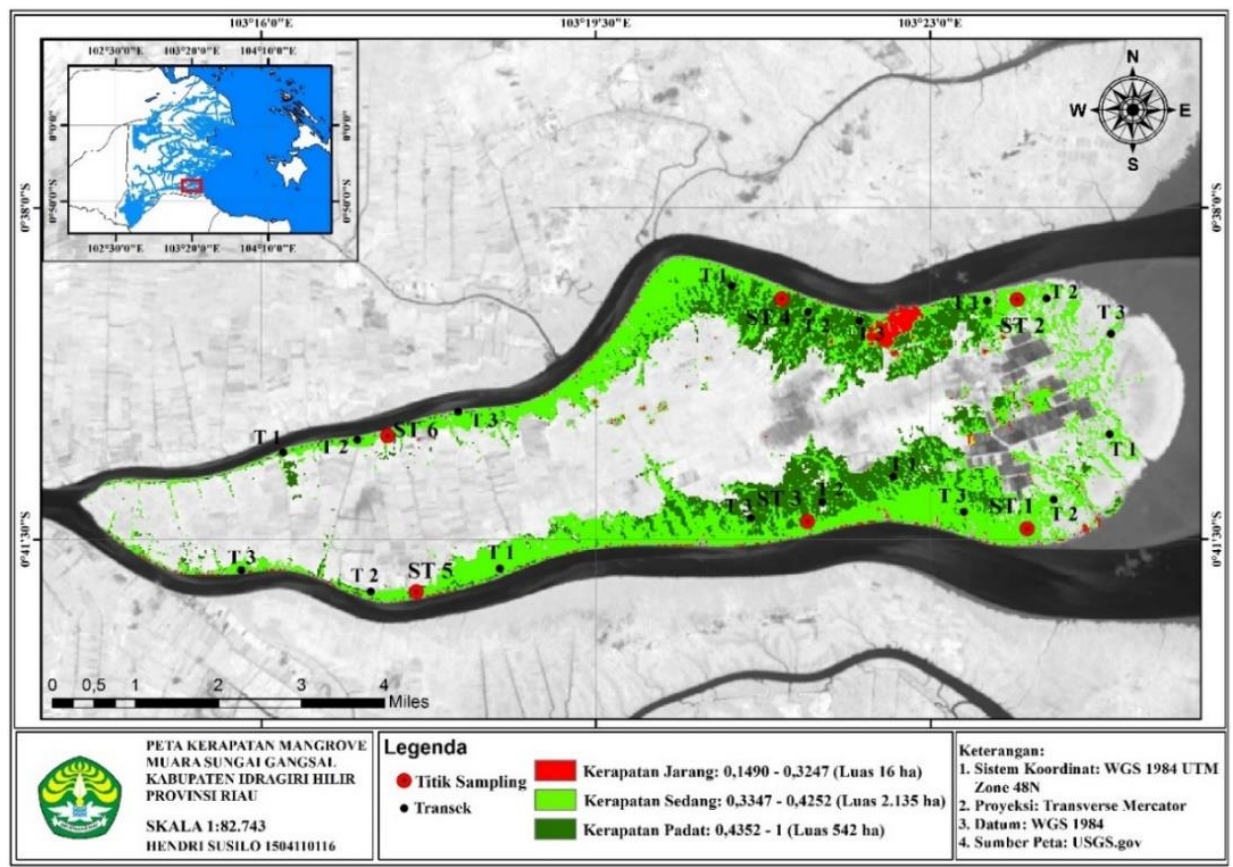

Gambar 4. Peta Kerapatan Vegetasi Mangrove di Muara Sungai Gangsal Tahun 2018.

Perubahan luas kriteria kerapatan vegetasi mangrove berdasarkan nilai NDVI dari tahun 2008 sampai tahun 2018 dapat dilihat pada Tabel 3 .

Tabel 3. Klasifikasi Kerapatan Berdasarkan Nilai NDVI

\begin{tabular}{llll}
\hline No. & Kriteria & Luas NDVI 2008 (ha) & Luas NDVI 2008 (ha) \\
\hline 1 & Jarang & 133 & 16 \\
2 & Sedang & 2.009 & 2.135 \\
3 & Padat & 564 & 542 \\
\hline & Total & 2.706 & 2.693 \\
\hline
\end{tabular}


Kerapatan vegetasi mangrove kriteria jarang dari tahun 2008 hingga tahun 2018 terdeteksi pada stasiun I dan II. Kriteria kerapatan jarang mengalami pengurangan luas dari 133 ha menjadi 16 ha. Berkurangnya luas vegetasi mangrove kriteria jarang diakibatkan oleh penebangan untuk alih fungsi lahan menjadi tambak milik masyarakat dan pembuatan jalan akses ke perkebunan.

Kriteria kerapatan sedang tahun 2008 hingga 2018 terdeteksi pada stasiun V dan VI. Kriteria kerapatan sedang mengalami pertambahan luas dari 2.009 ha menjadi 2.135 ha. Penambahan luas kerapatan kriteria sedang disebabkan pada stasiun $\mathrm{V}$ dan VI banyak ditemui aliran anak sungai dan irigasi yang membantu penyebaran dan distribusi biji buah dan propagul mangrove yang terbawa ke hulu anak sungai dan aliran irigasi pada saat air pasang dan surut, sehingga mangrove kriteria sedang tumbuh dengan baik dan mengalami penambahan luas.

Kriteria kerapatan padat tahun 2008 hingga 2018 terdeteksi pada stasiun III dan IV. Kriteria kerapatan padat mengalami pengurangan luas 546 ha menjadi 542 ha. berkurangnya luas vegetasi mangrove kriteria jarang diakibatkan oleh penebangan oleh masyarakat pesisir untuk bahan baku bangunan.

\section{Kerapatan Vegetasi Mangrove Tiap Stasiun Pada Tahun 2018 Berdasarkan Struktur Komunitas}

Kerapatan vegetasi mangrove berdasarkan struktur komunitas tingkat pohon tiap stasiun sampling disajikan pada Tabel 4.

Tabel 4. Kerapatan Vegetasi Mangrove Tiap Stasiun pada Tahun 2018

\begin{tabular}{lcccccc}
\hline \multirow{2}{*}{ Jenis Mangrove } & \multicolumn{7}{c}{ Stasiun } \\
\cline { 2 - 7 } & I & II & III & IV & V & VI \\
\hline Avicennia alba & + & + & + & + & - & - \\
Avicennia marina & + & + & + & + & - & - \\
Bruguiera cylindrica & - & - & + & + & - & - \\
Bruguiera sexangula & - & - & + & + & + & + \\
Nypa fruticans & - & - & + & + & + & + \\
Rhizophora apiculata & - & - & - & + & + & + \\
Sonneratia alba & + & + & + & + & - & - \\
Sonneratia caseolaris & - & - & + & + & + & + \\
\hline Kerapatan (ind/ha) & 922 & 866 & 1.522 & 1.511 & 1.255 & 1.044 \\
\hline Keterangan
\end{tabular}

Keterangan : $(+)=$ Ditemukan

$(-)=$ Tidak Ditemukan

Kerapatan vegetasi mangrove berdasarkan struktur komunitas tiap stasiun pada tahun 2018 dari 6 stasiun titik sampling berkisar $866 \mathrm{ind} / \mathrm{ha}$ hingga 1.522 ind/ha. Berdasarkan kerapatan vegetasi mangrove tiap stasiun pada tahun 2018, kerapatan terendah terdeteksi pada stasiun II dan kerapatan tertinggi pada stasiun III.

Kriteria kerapatan jarang terdeteksi pada titik stasiun I dan II, dengan nilai kerapatan masing-masing 922,22 ind/ha dan 866,67 ind/ha. Berdasarkan kriteria kerapatan pohon mangrove pada KepMen KLH No. 201/2004. Kerapatan mangrove stasiun I dan II dalam kriteria kerapatan jarang. Pada stasiun V dan VI ditemukan spesies mangrove Avicennia alba, Avicennia marina dan Sonneratia caseolaris.

Kriteria kerapatan sedang terdeteksi padat titik stasiun $\mathrm{V}$ dan VI, dengan nilai kerapatan masing-masing sebesar 1.255 ind/ha dan $1.044 \mathrm{ind} / \mathrm{ha}$ sehingga dalam kategori kerapatan sedang. Pada stasiun V dan VI ditemukan spesies mangrove Bruguiera sexangula, Nypa fruticans, Rhizophora apiculata dan Sonneratia caseolaris. 
Kriteria kerapatan padat terdeteksi pada titik stasiun III dan IV, dengan kerapatan masing-masing sebesar 1.522 ind/ha dan $1.511 \mathrm{ind} / \mathrm{ha}$ dengan kriteria kerapatan padat, sehingga dalam kriteria kerapatan padat. Pada titik stasiun III dan IV di ditemukan semua jenis mangrove dari semua komposisi mangrove yang ditemukan di Muara Sungai Gangsal.

\section{KESIMPULAN DAN SARAN}

\section{Kesimpulan}

Luas vegetasi mangrove dari tahun 2008, 2.706 ha dan tahun 2018, 2.693 ha. Terjadi pengurangan luas sebaran 13 ha. Kerapatan vegetasi mangrove berdasarkan nilai NDVI pada tahun 2008, kriteria jarang 133 ha, sedang 2.009 ha, padat 564 ha. Tahun 2018 keriteria jarang 16 ha, sedang 2.135 ha, padat 542 ha. Berdasarkan struktur komunitas tahun 2018, kerapatan jarang terdeteksi pada stasiun I dengan kerapatan $922 \mathrm{ind} / \mathrm{ha}$ dan staiun II 866 ind/ha. Kriteria kerapatan sedang terdeteksi pada stasiun $\mathrm{V}$ dengan kerapatan 1.255 ind/ha dan stasiun VI 1.044 ind/ha. Kriteria kerapatan padat terdeteksi pada stasiun III dengan kerapatan $1.522 \mathrm{ind} / \mathrm{ha}$ dan stasiun IV $1.511 \mathrm{ind} / \mathrm{ha}$.

\section{Saran}

Penelitian tentang pemetaan vegetasi mangrove sebaiknya dilakukan penelitian lanjutan agar diperoleh data secara temporal untuk memonitoring vegetasi mangrove di Muara Sungai Gangsal. Penelitian selanjutnya sebaiknya menggunakan citra dengan resolusi tinggi dan relatif bersih dari awan agar hasil klasifikasi lebih akurat dan bagus.

\section{DAFTAR PUSTAKA}

1. Aji, A. A., J. Sartohadi., T. S. Djohan dan S. Ritohardoyo. (2017). Erosi Pantai, Ekosistem Hutan Bakau dan Adaptasi Masyarakat Terhadap Bencana Kerusakan Pantai di negara Tropis. Jurnal Ilmu Lingkungan, Volume 15(1), Pages 1-10.

2. Amliana, D.R., Y. Prasetyo dan A. Sukmono. (2016). Analisis Perbandingan Nilai Ndvi Landsat 7 dan Landsat 8 Pada Kelas Tutupan Lahan. Jurnal Geodesi Undip, Volume 5(1), Pages 264-247.

3. Bangun, M. S danY. N. Arindi. (2019). Analisa Perubahan Kerapatan Mangrove Berdasarkan Nilai Normalized Difference Vegetation Index Menggunakan Citra Landsat 8 (Studi Kasus: Pesisir Utara Surabaya). Jurnal Geoid, Volume 14(2), Pages $1-5$.

4. Cecep, K dan D. R. P. Ningrum. (2016). Tipologi dan Kondisi Vegetasi Kawasan Mangrove Bulaksetra Kabupaten Pangandaran Provinsi Jawa Barat. Jurnal Silvikultur Tropika, Volume 7(2), Pages 137-145.

5. Fatimah, P. U., Y. Prasetyo dan A. Sukmono. (2016). Analisis Spasial Perubahan Luasan Mangrove Akibat Pengaruh Limpasan Sedimentasi Tersuspensi Dengan Metode Penginderaan Jauh. Jurnal Geodesi Undip, Volume 5(1), Pages 305-315.

6. Hendrawan, J.I. Gaol dan S.B. Susilo. (2018). Studi Kerapatan Dan Perubahan Tutupan Mangrove Menggunakan Citra Satelit Di Pulau Sebatik Kalimantan Utara. Jurnal Ilmu dan Teknologi Kelautan Tropis, Volume 10(1), Pages 99-109.

7. Intan, P., L. Saputra., L. Harvianto dan A. A. Muzaki. (2016). Pemetaan Vegetasi Hutan Mangrove Menggunakan Metode Normalized Difference Vegetation Index (NDVI) Di Desa Arakan, Minahasa Selatan, Sulawesi Utara. Surya Octagon Interdisciplinary Journal of Technology, Volume 1(2), Pages 211-222.

8. Kementerian Negara Lingkungan Hidup. (2004). KepMen LH No. 201 Tentang Keriteri Baku dan Pedoman Penentuan Kerusakan Mangrove. (p. 62). Jakarta: Deputi MENLH Bidang Kebijakan dan Kelembagaan Lingkungan Hidup. 
9. Kurniawan, H., A. Takwir dan Halili. (2019). Pemetaan Batimetri Perairan Dangkal Menggunakan Algoritma Jupp Pada Citra Spot-7 di PerairanTanjung Tiram. Jurnal Sapa, Volume 4(1), Pages 1-12.

10. Lilik, K., A. P. Wijaya dan A. Sukmono. (2016). Analisis Pengaruh Koreksi Atmosfer Terhadap Estimasi Kandungan Klorofil-A Menggunakan Citra Landsat 8. Jurnal Geodesi Undip, Volume 5(4), Pages 56-64.

11. Muhammad, A. A., B. Sudarsono dan N. Bashit. (2019). Analisis Perbandingan Peningkatan Sedimentasi Di Waduk Mrica Dengan Perubahan Tutupan Lahan Pada Daerah Aliran Sungai (Das) Merawu Menggunakan Data Citra Satelit Landsat. Jurnal Geodesi Undip, Volume 8(1), Pages 388-397.

12. Nadya, F. N., L. D. Mustafa dan P. Elfa. (2019). Analisa Perubahan Luas dan Kerapatan Mangrove Melalui Pengolahan Citra Satelit Landsat 8. Jurnal JARTEL, Volume 9(2), Pages 17-24.

13. Nurul, L., S. Febrianto, H. Endrawati dan M. Zainuri. (2018). Pemetaan Klasifikasi dan Analisa Perubahan Ekosistem Mangrove Menggunakan Citra Satelit Multi Temporal di Karimunjawa, Jepara, Indonesia. Jurnal Kelautan Tropis, Volume 21(2), Pages 97-102.

14. Pinastika. N., S. Subiyanto dan B. Sasmito. (2013). Pemetaan Total Suspended Solid (TSS) Menggunakan Citra Satelit Multi Temporal di Danau Rawa Pening Provinsi Jawa Tengah. Jurnal Geodesi Undip, 2(4), Pages 72-84.

15. Pratama, I. G. Y., I.W. G. A. Karang dan Y. Suteja. (2019). Distribusi Spasial Kerapatan Mangrove Menggunakan Citra Sentinel-2A Di TAHURA Ngurah Rai Bali. Journal of Marine and Aquatic Sciences. Volume 5(2), Pages 192-202.

16. Rumada, I.W., A.A. Kusumadewi dan R. Suyarto. (2015). Interpretasi Citra Satelit Landsat 8 untuk Identifikasi Kerusakan Hutan Mangrove di Taman Hutan Raya Ngurah Rai Bali. Jurnal Agroeteknologi Tropika, Volume 4(3), Pages 1-10.

17. Susiana. (2015). Analisis Kualitas Air Ekosistem Mangrove Di Estuari Perancak, Bali. Jurnal Ilmiah agribisnis dan Perikanan, Volume 8(1), Pages 42-49. 